\title{
PRAANGGAPAN DALAM TINDAK TUTUR TAYANGAN “BOCAH NGAPA(K) YA” DI TRANS 7
}

\author{
Fitri Liantari ${ }^{1)}$, A. Rahman ${ }^{2)}$, Rohmah Tussolekha ${ }^{3)}$ \\ ${ }^{123}$ FKIP, Universitas Muhammadiyah Pringsewu Lampung \\ Pos-el: fitriliantari@gmail.com, rohmahtussolekha@umpri.ac.id.
}

\begin{abstract}
Abstrak
Penelitian ini bertujuan untuk mendeskripsikan jenis praanggapan yang terdapat dalam tindak tutur tayangan Bocah Ngapa(k) Ya di TRANS 7. Bocah Ngapa $(k) Y a$ merupakan tayangan televisi bergenre komedi. Jenis penelitian ini adalah analisis deskriptif kualitatif. Pengumpulan data dalam penelitian ini menggunakan teknik catat. Analisis data dilakukan dengan membahas tindak tutur dalam tayangan Bocah Ngapa(k) $\mathrm{Ya}$ kemudian menganalisis pranggapan yang terdapat dalam tindak tutur tayangan tersebut. Sampel data yang digunakan dalam penelitian ini sebanyak empat episode. Berdasarkan hasil penelitian ditemukan Tindak Tutur Ekspresif yang mengandung Praanggapan Leksikal, Tindak Tutur Representatif yang mengandung Praanggapan Konterfaktual, Tindak Tutur Direktif yang mengandung Praanggapan Nonfaktual, Tindak Tutur Representatif yang mengandung Praanggapan Leksikal dan Eksistensial, Tindak Tutur Representatif yang mengandung Praanggapan Faktual, dan Tindak Tutur Representatif yang mengandung Praanggapan Leksikal.

Kata kunci: tindak tutur, praanggapan, tayangan televisi.
\end{abstract}

\begin{abstract}
This study aims to describe the types of presuppositions contained in the speech act of Bocah Ngapa(k) Ya in TRANS 7. Bocah Ngapa(k) Ya is a comedy genre television show. This type of research is a qualitative descriptive analysis. Collecting data in this study using a note-taking technique. Data analysis was carried out by discussing the speech acts in the show Bocah Ngapa(k) Yes and then analyzing the presuppositions contained in the speech acts of the show. The sample data used in this study were four episodes. Based on the research results, it was found that expressive speech acts contain lexical presuppositions, representative speech acts contain counterfactual presuppositions, directive speech acts contain non-factual presuppositions, representative speech acts contain lexical and existential presuppositions, representative speech acts contain factual presuppositions, and representative speech acts contain factual presuppositions. Containing Lexical Presumptions. Keywords: speech acts, presuppositions, television shows.
\end{abstract}




\section{PENDAHULUAN}

Bahasa merupakan sistem lambang bunyi ujaran yang digunakan untuk berkomunikasi. Dalam pembelajaran Bahasa Indonesia, kajian Pragmatik sebagai telaah mengenai relasi antarbahasa dan konteks dasar bagi suatu catatan atau laporan pemahaman bahasa. Pragmatik merupakan telaah mengenai relasi antara bahasa dan konteks yang merupakan dasar bagi suatu pemahaman bahasa, pemakai bahasa dalam menghubungkan serta menyerasikan kalimat-kalimat dan konteks secara tepat. Penggunaan bahasa dalam kehidupan sehari-hari sering terjadi salah paham yang menyebabkan informasi dan maksud dari sebuah ujaran yang tidak tersampaikan dengan baik. Oleh karena itu, manusia harus dapat memahami makna dan maksud dari tuturan yang diucapkan oleh lawan tuturnya serta tidak hanya mengerti apa yang telah diujarkan oleh penutur, tetapi juga konteks yang digunakan dalam ujaran.

Menurut Levinson (dalam Eva Eri, 2012:1), pragmatik merupakan studi bahasa yang mempelajari relasi bahasa dengan konteksnya. Konteks yang dimaksud telah tergramatisasi dan terkodifisikan sedemikian rupa sehingga tidak dapat dilepaskan dari struktur bahasanya.

Levinson (dalam Tarigan: 2009:31) mendefinisikan pragmatik adalah telaah mengenai relasi antara Bahasa dan konteks yang merupakan dasar bagi suatu catatan atau laporan pemahaman bahasa, dengan kata lain telaah mengenai kemampuan pemakai Bahasa menghubungkan serta penyerasian kalimat-kalimat dan konteks-konteks secara tepat.

Pragmatik mengkaji bentuk bahasa untuk memahami maksud penutur. Pragmatik adalah studi pustaka yang mendasarkan prinsip analisisnya pada konteks. Tanpa adanya konteks, maka maksud yang ingin disampaikan bisa tidak jelas bahkan tidak dapat dimengerti atau diterima oleh penuturnya. Pada era ini banyak tayangan acara televisi yang menarik perhatian penonton salah satunya adalah Bocah Ngapa(k) Ya. Tayangan tersebut merupakan tayangan yang televisi bergenre komedi dan banyak terdapat praanggapan yang tidak terduga dalam peristiwa tutur yang terjadi di saat interaksi percakapan yang dilakukan oleh penutur dan lawan tutur. Peristiwa tutur merupakan peristiwa sosial karena menyangkut pihak-pihak yang bertutur 
Fitri Liantari, A. Rahman, Rohmah Tussolekha...

dalam satu situasi dan tempat tertentu. Peristiwa tutur merupakan rangkaian dari sejumlah tindak tutur yang terorganisasikan untuk mencapai suatu tujuan.

Abdul Chaer (2010:49-50) menyatakan bahwa tindak tutur adalah suatu peristiwa tutur yang pada dasarnya merupakan rangkaian dari sejumlah tindak tutur yang terorganisasikan untuk mencapai suatu tujuan. Kalau peristiwa tutur merupakan gejala sosial, maka tindak tutur merupakan gejala individual, bersifat psikologi dan keberlangsungannya ditentukan oleh kemampuan bahasa penutur dalam menghadapi situasi tertentu. Dalam peristiwa tutur lebih dilihat tujuan peristiwanya, tetapi dalam tindak tutur lebih dilihat makna atau arti tindakan dalam tuturannya. Tindak tutur dan peristiwa tutur merupakan dua gejala yang terdapat pada satu proses, yaitu proses komunikasi.

Praanggapan adalah bagian dari pragmatik yang mengaitkan dua proposisi sehingga dapat dipahami maknanya. Praanggapan didapatkan dari pernyataan yang disampaikan tanpa perlu ditentukan apakah praanggapan tersebut benar atau salah, yang mengacu pada penyataan sebenarnya. Praanggapan merupakan sesuatu yang diduga oleh penutur sebagai kejadian sebelum menghasilkan suatu tuturan. Seseorang dapat mengidentifikasi tuturan sebagai informasi yang diduga secara tepat dan akan dihubungkan dengan pengetahuan yang dimilikinya. Melalui komunikasi informasi yang disampaikan penutur kepada lawan tutur akan menjadi dugaan awal yang didapat oleh lawan tutur.

Menurut Yule (dalam Eva Eri, 2012:12) "Praanggapan merupakan sesuatu yang diasumsikan oleh penutur sebagai kejadian sebelum menghasilkan sebuah tuturan". Praanggapan berupa andaian dari penutur, bahwa lawan tutur dapat mengetahui maksud dari apa yang dibicarakan. Lawan tutur akan memahami dan mengetahui sesuatu yang dituturkan oleh penutur. Jadi pemahaman tentang praanggapan oleh lawan tutur karena adanya tuturan memperanggapkan yang dinyatakan oleh penutur.

Bocah Ngapa(k) Ya adalah acara televisi Indonesia bergenre komedi dengan menggunakan bahasa Jawa Ngapak yang ditayangkan oleh stasiun televisi TRANS7. Jawa Ngapak merupakan Bahasa Jawa yang digunakan dengan dialek khas, memiliki intonasi yang berbeda dari Bahasa Jawa umumnya. Bahasa Jawa Ngapak digunakan oleh masyarakat di wilayah Jawa Tengah bagian Barat. Tayangan 
tersebut berupa tuturan-tuturan humor yang dilakukan oleh tiga orang anak bernama Ilham, Azkal, dan Fadli yang memiliki hubungan pertemanan dan menceritakan kehidupan mereka seharisehari. Pada tayangan tersebut terdapat anggapan-anggapan tidak terduga yang mengecoh penonton. Anggapan yang mengecoh penonton dapat terjadi di dalam peristiwa tutur Bocah Ngapa(k) Ya.

Telaah dalam tayangan Bocah Ngapa(k) Ya sangat diperlukan. Ragam bahasa yang terdapat dalam tayangan Bocah Ngapa(k) $\quad Y a \quad$ mengandung fenomena bahasa yang kaya salah satunya adalah fenomena penggunaan praanggapan. Serta tayangan Bocah Ngapa(k) Ya dapat digunakan sebagai media pembelajaran.

Telah banyak pembahasan tentang praanggapan salah satunya dari Andryanto, S.F. (2014), yang membahas mengenai praanggapan yang ada di tayangan SKETSA di TRANS 7 dengan simpulan bahwa penting untuk memahami praanggapan agar tidak terjadi kesalahpahaman antara penutur dan mitra tutur. Pembahasan praanggapan lainnya disampaikan oleh (Retnosari, 2014) yang menyimpulkan bahwa adanya kemampuan yang lebih untuk memahami praanggapan agar dapat meningkatkan kualitas komunikasi.
Berbeda dengan penelitian yang sebelumnya, peneliti mengungkapkan jenis praanggapan yang muncul dalam tindak tutur tayangan Bocah Ngapa(k) Ya. Penelitian praanggapan pada tayangan Bocah Ngapa (k) Ya perlu dilakukan karena tayangan mempunyai ciri khas tertentu yaitu konteks yang melingkupi percakapan di dalamnya. Hal lain ialah peneliti ingin membantu para pembaca dalam menentukan maksud yang ingin disampaikan dari berbagai praduga yang muncul dalam tayangan Bocah Ngapa(k) $Y a$.

\section{METODE PENELITIAN}

Metode yang digunakan dalam penelitian ini adalah deskriptif dengan bentuk penelitian kualitatif. Menurut Sugiyono (2017:401) dalam penelitian kualitatif merupakan teknik pengumpulan data yang utama adalah observasi partisipan, wawancara mendalam, studi dokumentasi, dan gabungan ketiganya atau triangulasi.

Penelitian kualitatif adalah suatu bentuk penelitian yang dilakukan dengan menganalisis data-data yang diperoleh dari hasil penelitian. Penelitian ini menghasilkan data, baik berupa kata-kata atau ujaran maupun kutipan kalimat yang ada dalam tayangan Bocah Ngapa(k) Ya. 
Sumber data dikumpulkan dari berbagai sumber, yang meliputi: transkrip/salinan, yaitu dokumen baik berupa catatan maupun video acara Bocah Ngapa(k) Ya yang ditayangkan di TRANS 7. Arikunto (2012:72) menjelaskan sumber data dalam penelitian adalah subjek dari mana data diperoleh. Data dalam penelitian ini berupa transkripsi teks tuturan yang mengandung praanggapan dalam tayangan Bocah Ngapa (K) Ya. Teknik yang digunakan adalah teknik simak catat yaitu menyimak acara Bocah Ngapa(k) Ya yang ditayangkan di televisi dan youtube. Alat pengumpulan data yang digunakan dalam penelitian ini yaitu alat tulis dan laptop.

Teknik analisis data merupakan data yang sudah dikumpulkan peneliti secara keseluruhan. Analisis data merupakan upaya yang dilakukan untuk mengklasifikasikan, mengelompokan, dan menyamakan data yang sama serta membedakan data yang berbeda (Mahsun, 2014:253). Acara Bocah Ngapa(k) Ya merupakan acara hiburan yang ditayangkan di TRANS 7. Peneliti akan menganalisis acara Bocah Ngapa(k) Ya yang ditayangkan pada tanggal 16 Februari-16 Maret 2019 yang berjumlah empat video atau empat episode dan masing-masing video berdurasi 17-20 menit dengan rentang waktu satu bulan.
Data dalam penelitian ini adalah praanggapan pada tindak tutur tayangan Bocah Ngapa(k) Ya di TRANS 7. Tindak tutur yang memiliki tema tentang pendidikan, yang terdapat pada tayangan Bocah Ngapa(k) Ya. Dalam penelitian ini, peneliti menganalisis jenis-jenis praanggapan pada tindak tutur tayangan Bocah Ngapa(k) Ya di TRANS 7. Teknik analisis dalam penelitian ini dilakukan melalui beberapa tahap yaitu: 1) tahap pemahaman praanggapan, mentranskripkan data hasil melihat tayangan Bocah Ngapa(k) Ya ke dalam bentuk teks tulisan, 3) mengelompokkan data sesuai jenis masalah, yaitu jenis praanggapan dalam tindak tutur tayangan Bocah Ngapa(k) Ya, data yang telah terkumpul dideskripsikan praanggapannya, 4) data dianalisis dengan mengacu pada teori yang dijadikan sebagai landasan penelitian, 5) peneliti melakukan evaluasi secara menyeluruh dan tahap penarikan kesimpulan.

\section{HASIL DAN PEMBAHASAN}

Berdasarkan hasil analisis data, peneliti menemukan tindak tutur yang terdapat dalam tayangan Bocah Ngapa(k) $Y a$ di TRANS 7 (episode 1-4), yaitu tindak tutur representatif, tindak tutur ekspresif, dan tindak tutur direktif. 
Sementara itu, praanggapan yang ditemukan berdasarkan hasil analisis data yaitu praanggapan leksikal, faktual, nonfaktual, eksistensial, dan konterfaktual. Berikut pembahasan tindak tutur dalam tayangan Bocah Ngapa(k) Ya.

1) Tindak Tutur Ekspresif yang Mengandung Praanggapan

\section{Leksikal}

Tindak tutur ekspresif adalah tindak tutur yang dimaksudkan penuturnya agar si lawan tutur menganalisis apa yang diucapkan oleh penutur. Tindak tutur ekspresif mempunyai fungsi untuk mengekspresikan, mengungkapkan, atau memberitahukan sikap psikologis sang pembicara menuju suatu pernyataan keadaan yang diperkirakan oleh ilokusi.

Konteks: "Di teras rumah terlihat tiga anak yang sedang duduk tetepi salah satu dari ketiga anak tersebut terlihat sedih karena kucing kesayangnya telah hilang”.

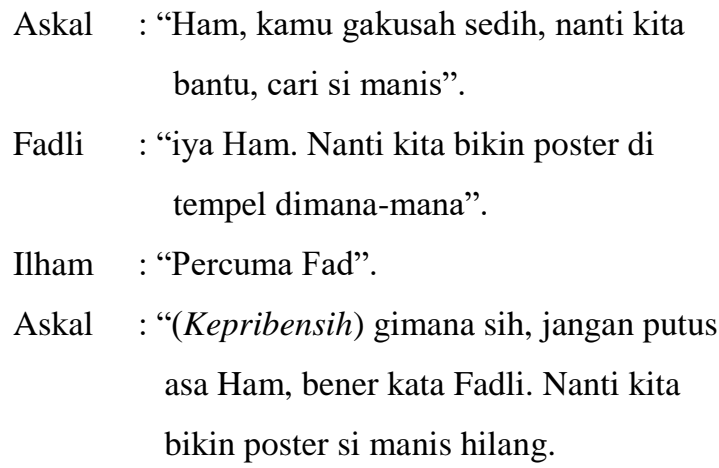
Ilham : "percuma bikin poster kan simanis tidak bisa baca".

Tindak tutur tersebut merupakan tindak tutur ekspresif yang terletak pada kalimat yang diungkapkan oleh penutur (Ilham) kepada lawan tutur (Askal dan Fadli) yang mengatakan "percuma Fad". Kalimat tersebut mengandung sebuah maknabahwa percuma atau sia-sia. Tindak tutur tersebut juga mengandungpraanggapan leksikal karena kata percuma memiliki arti leksikal dan adanya penegasan pada kata tersebut yang mengandung praanggapan penutur bahwa percuma atau sia-sia membuat poster si manis (kucing) hilang karena penutur memiliki praanggapan bahwa kucing tidak bisa membaca. Akan tetapi, lawan tutur memiliki praanggapan lain dan menanggapinya dengan tegas "gimana sih, jangan putus asa Ham, bener kata Fadli. Nanti kita bikin poster si manis hilang”. Kalimat tersebut mengandung arti bahwa ilham merasa putus asa.

2) Tindak Tutur Representatif yang Mengandung Praanggapan

\section{Konterfaktual}

Tindak tutur representatif adalah tindak tutur yang melibatkan pembicara pada kebenaran proposisi yang diekspresikan, misalnya: menyatakan, 
Fitri Liantari, A. Rahman, Rohmah Tussolekha...

memberitahukan, menyebutkan, membanggakan, mengeluh, menuntut, melaporkan, dan menunjukkan.

Konteks: "Azkal, Fadli dan Ilham sedang duduk-duduk di pimggir sawah sambil menikmati pemandangan yang indah".

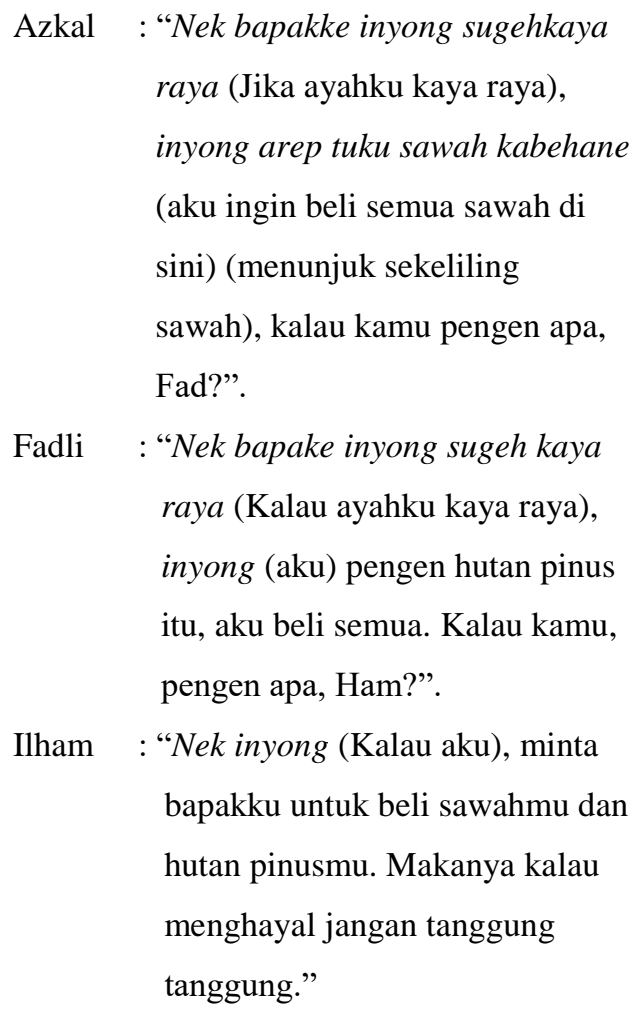

Peristiwa tutur tersebut bisa dilihat adanya wujud tindak tutur representatif karena penutur memberitahukan bahwa penutur bukan orang kaya raya yang terletak pada kalimat yang dituturkan oleh Azkal "Jika ayahku kaya raya", Kalimat yang dituturkan oleh Fadli "Kalau ayahku kaya raya", dan kalimat yang dituturkan oleh Ilham "Kalau aku, minta bapakku untuk beli sawahmu dan hutan pinusmu."
Tindak tutur tersebut juga mengandung praanggapan konterfaktual karena Azkal, Fadli dan Ilham bukanlah orang kaya raya yang memiliki sawah luas dan hutan pinus.

\section{3) Tindak Tutur Direktif yang Mengandung Praanggapan Nonfaktual}

Tindak tutur direktif adalahtindak tutur yangmenimbulkan beberapa efek melalui tindakan sang penyimak, misalnya: memesan, memerintahkan, memohon, meminta, menyarankan, menganjurkan, menasehatkan.

Konteks: "Azkal kelaparan saat sedang bermain dengan Fadli dan Ilham, kemudian Azkal mengajak patungan untuk membeli makanan bakso supaya kenyang. Azkal dan Fadli menyuruh Ilham untuk membeli bakso."

Azkal : "(Megang pundak Ilham) Ham, sekarang beli bakso. Fadli bakso satu, inyong (aku) satu, kamu sekalian jadinya berapa?".

Ilham : "Dua(kekeh dengan jawabannya dua bakso)".

Azkal : "Bener, Fad. Emosi inyong (aku), Fad (mulai terbawa emosi) Ham, aku ulangi lagi ya? Fadli bakso satu, inyong (aku) satu, kamu sekalian jadinya berapa?".

Ilham : "Dua". 


\author{
Azkal dan Fadli :"(Menjerit) Tigaaa!!”. \\ Ilham : : "(Menutup telinganya) ya dua \\ lah, aku kan mie ayam, bukan \\ bakso."
}

Peristiwa tutur tersebut bisa dilihat adanya tindak tutur direktif karena penutur memerintahkan kepada lawan tuturnya yang terletak pada kalimat "Ham, sekarang beli bakso. Fadli bakso satu, aku satu, kamu sekalian jadinya berapa?" Tindak tutur tersebut juga mengandung praanggapan nonfaktualkarena Azkal dan Fadli berasumsi Ilham juga ingin memesan bakso dan jumlah yang harus dibeli yaitu tiga bungkus bakso, namun kenyataannya Ilham tidak ingin membeli bakso melainkan mie ayam.

\section{4) Tindak TuturRepresentatif yang Mengandung Praanggapan}

\section{Leksikal dan Eksistensial}

Tindak tutur representatif adalah tindak tutur yang melibatkan pembicara pada kebenaran proposisi yang diekspresikan, misalnya: menyatakan, memberitahukan, menyebutkan, membanggakan, mengeluh, menuntut, melaporkan, menunjukkan dll.
Konteks: "Azkal, Fadli dan Ilham berkunjung ke rumah Pak RT untuk menjenguk Pak RT yang sedang sakit dan menawarkan untuk meminum obat 1001 macam penyakit yang dititipkan oleh Neneknya Fadli."

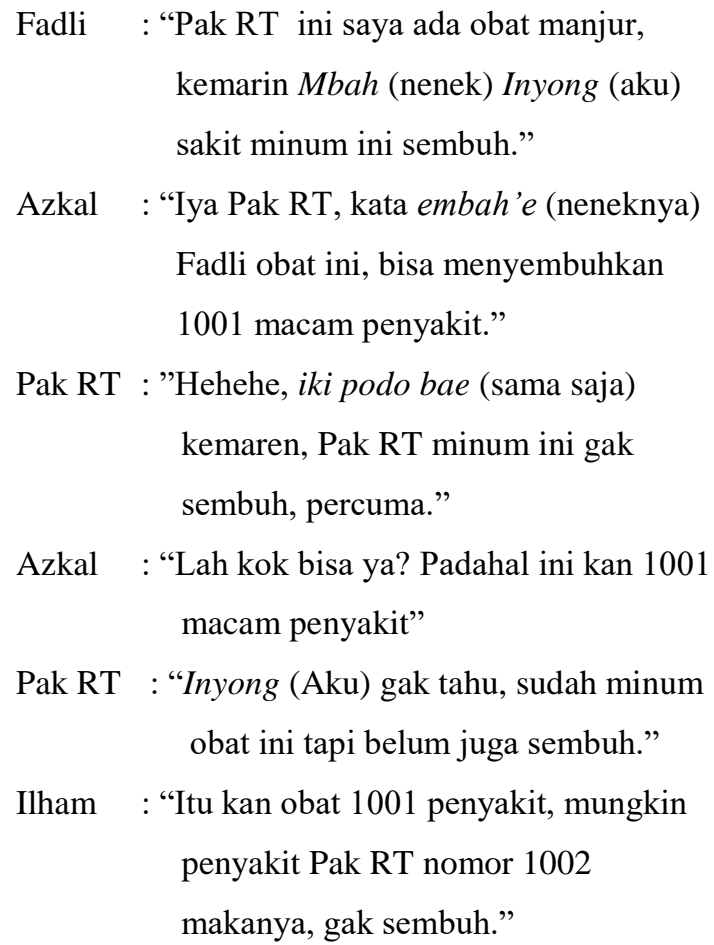

Tindak tutur tersebut merupakan tindak tutur representatif karena penutur memberitahukan bahwa kemarin sudah minum obat 1001 macam penyakit tetapi tetap saja tidak sembuh yang terletak pada kalimat yang dituturkan oleh Pak RT "Hehehe, sama saja. Kemaren, Pak RT minum ini gak sembuh. Percuma”. Tindak tutur tersebut juga mengandung praanggapan leksikalkarena Pak RT memiliki praanggapan minum obat 1001 
Fitri Liantari, A. Rahman, Rohmah Tussolekha...

macam penyakit tidak ada gunanya karena sudah minum tetapi tetap saja tidak sembuh.

Kalimat yang dituturkan oleh
Ilham merupakan tindak tutur representatif karena menyatakan penyakit Pak RT nomor 1002 yang terletak pada kalimat "Itu kan obat 1001 macam penyakit, mungkin penyakit $\mathrm{Pk}$ RT nomor 1002, makanya gak sembuh" Tindak tutur tersebut juga mengandung praanggapan eksistensial karena Ilham berasumsi obat 1001 macam penyakit hanya dapat menyembuhkan penyakit sampai nomor 1001 dan Ilham menyatakan keberadaan setelah nomor 1001 selanjutnya nomor 1002.

5) Tindak Tutur Representatif yang Mengandung Praanggapan Faktual

Tindak tutur representatif adalah tindak tutur yang melibatkan pembicara pada kebenaran proposisi yang diekspresikan, misalnya: menyatakan, memberitahukan, menyebutkan, membanggakan, mengeluh, menuntut, melaporkan, menunjukkan, dan lain-lain.

Konteks: “Azkal, Fadli dan Ilham belajar bersama di ruang tamu kemudian mereka mengadakan tes tanya jawab tentang pribahasa."

Ilham $\quad$ : "Manusia mati meninggalkan
apa? Ayo siapa yang bisa
jawab?".
Azkal : "Inyong (Aku) bisalah, manusia
mati meninggalkan nama."
Fadly : "Iya, inyong (aku) juga bisa,
$\quad$ benar itu jawaban Azkal."
Ilham : "Salah, Manusia mati adalah
meninggalkan keluarganya."

Kalimat yang dituturkan oleh Azkal dan Ilham merupakan tindak tutur representatif karena Azkal memberitahukan bahwa ia dapat menjawab pertanyaan dari Ilham yang terletak pada kalimat "Aku bisalah, manusia mati meninggalkan nama". Kemudian Ilham menyatakan bahwa jawaban Azkal salah yang terletak pada kalimat "Salah, Manusia mati adalah meninggalkan keluarganya”. Tindak tutur tersebut juga mengandung praanggapan faktual karena Azkal memiliki praanggapan manusia mati meninggalkan nama maksudnya orang yang baik akan meninggalkan nama baik dan orang yang jahat akan meninggalkan nama buruk yang tercemar. Namun Ilham memilki praanggapan lain karena faktanya setiap manusia pasti akan meninggalkan 
keluarga yang dicintainya bahkan harta benda dan hal lain yang bersifat duniawi.

\section{6) Tindak Tutur Representatif} yang Mengandung Praanggapan

\section{Leksikal}

Tindak tutur representatif adalah tindak tutur yang melibatkan pembicara pada kebenaran proposisi yang diekspresikan, misalnya: menyatakan, memberitahukan, menyebutkan, membanggakan, mengeluh, menuntut, melaporkan, menunjukkan dll.

Konteks : Azkal, Fadli dan Ilham belajar bersama. Kemudian Fadli memberikan pertanyaan kepada Azkal "siapa penemu lampu?" Azkal pum menjawab dengan benar lalu Azkal kembali bertanya "siapa penemu telepon?".

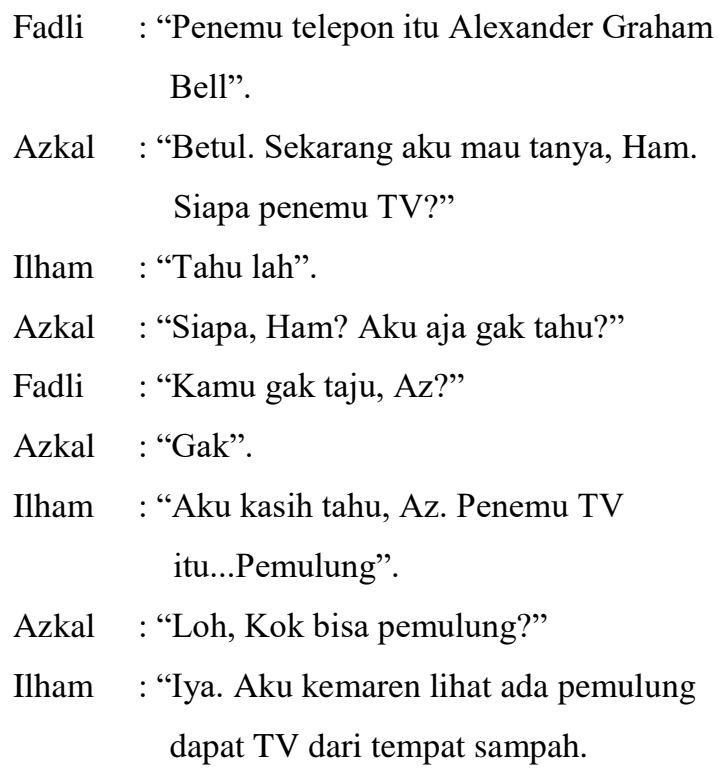

Tindak tutur yang dituturkan oleh Ilham merupakan tindak tutur Representatif.. Karena Ilham memberitahukan kepada Azkal dan Fadli bahwa ia melihat penemu TV yaitu pemulung, yang terletak pada kalimat "Aku kasih tahu, Az. Penemu TV itu...Pemulung". Dalam tindak tutur tersebut mengandung sebuah praanggapan leksikal yang terletak pada kata "pemulung" yang memiliki makna menemukan sesuatu benda atau alat yang belum diketahui orang. Ilham memiliki Praanggapan lain yaitu ia mengartikan penemu adalah pemungut atau mengambil, sedangkan pada kenyataannya yang dimaksud oleh Azkal dan Fadli penemu adalah menciptakan atau menemukan suatu alat yang belum diketahui orang, contohnya yang pertama kali menemukan telepon adalah Alexander Graham Bell.

\section{SIMPULAN}

Berdasarkan hasil analisis data dan pembahasan yang dilakukan dalam penelitian ini yang berkaitan dengan pembahasan jenis tindak tutur dan jenis praanggapan yang digunakan dalam tuturan tayangan Bocah Ngapa(k) $\mathrm{Ya}$ di TRANS 7 dapat diambil kesimpulan, tindak tutur yang terdapat dalam peristiwa 
tutur tayangan Bocah Ngapa(k) Ya di TRANS 7 (episode 1-4) memiliki tiga jenis tindak tutur yaitu tindak tutur representatif, tindak tutur ekspresif, dan tindak tutur direktif, praanggapan yang terkandung dalam tindak tutur tayangan Bocah Ngapa(k) Ya di TRANS 7 (episode 1-4) memiliki lima jenis praanggapan yaitu praanggapan leksikal, praanggapan faktual, praanggapan nonfaktual, praanggapan eksistensial, dan praanggapan konterfaktual. Berdasarkan temuan tersebut, data yang telah dianalisis peneliti berupa percakapan yang meliputi: 1) Tindak tutur ekspresif yang mengandung praanggapan leksikal, 2) Tindak tutur representatif yang mengandung praanggapan konterfaktual, 3) Tindak tutur direktif yang mengandung praanggapan nonfaktual, 4) Tindak tutur representatif yang mengandung praanggapan leksikal dan eksistensial, 5) Tindak tutur representatif yang mengandung praanggapan faktual, dan 6) Tindak tutur representatif yang mengandung praanggapan leksikal.

\section{DAFTAR PUSTAKA}

Abdul Chaer dan Leoni Agustina. (2010). Sosiolinguistik. Jakarta: PT Rineka Cipta.

Andriyanto, S.F., Andayani, Rohmadi, M. (2014). Analisis Praanggapan pada Percakapan SKETSA di Trans 7.
Jurnal Penelitian Bahasa, Sastra Indonesia dan Pengajarannya Vol. 02. No. 3., 1-16.

Eva Eri Dia. (2012). Analisis

Praanggapan. Malang: Madani.

Mahsun. (2014). Metode Penelitian

Bahasa: Tahapan Strategi, Metode, dan Tekniknya. Jakarta: Rajawali Press.

Retnosari, I.E. (2014). Praanggapan dan Implikatur dalam Mr. Pecut pada Jawa Pos. WAHANA, 63, 15-20.

Sugiyono. (2017). Metode Penelitian Kuantitatif, Kualitatif, dan $R \& D$. Bandung: Alfabeta.

Suharsimi Arikunto. (2012). Dasar-dasar Evaluasi Pendidikan. Jakarta: Bumi Aksara.

Tarigan, Henry Guntur. (2009).

Pengajaran Pragmatik. Bandung:

Angkasa. 